\title{
The Impact Of Tertiary Education On Development Of Moderate Society In Pakistan
}

\author{
Samrana Atika, UIER, PMAS Arid Agriculture University, Pakistan
}

\begin{abstract}
The study aimed to find out the impact of tertiary education on development of moderate Islamic society in Pakistan. The population of the study constituted of all the teachers engaged on teaching and all the students studying in the colleges. The study was delimited to the area of public sector college education. Cluster sampling technique was used for choosing a sample from 100 male and 100 female colleges. Three teachers and nine students were selected from each college. Two questionnaires were used as the research instruments for collection of data after pilot testing. Collected data was tabulated, analyzed and discussed category-wise as teachers and students. To analyze the data, mean, standard deviation, standard error of mean, estimated population mean and Z-Value were applied for getting the results. On the basis of the analysis it was concluded that college education promoted the modern way of life in society by giving sense o responsibility, improving women status and removing frustration. It improved confidence, awoke love feelings for country and the sense of responsibility.
\end{abstract}

Keywords: Moderate society; Moderation; Tertiary Education; College education; Moral Values

\section{INTRODUCTION}

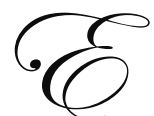

ducation is considered to be the main instrument of change in social sphere. By and large varieties of changes are taking place like economic change, social change and political change in the society (Chandra, 1997). Education opens new horizons for development and improvement of different factors which have direct impact on society. It helps in achieving all those targets which lead the nation towards progress and prosperity. Education is the balanced training of human mind which shows right direction to creative power and help to mould human thoughts, actions and character into the frame of higher values of society. If society desires to strengthen values and to mould individual's mind and action according to Islamic values, education can help to attain this objective (Sharif, 1990).

College education has a vital role to play because the susceptibility to change and capability for development among people is commensurate with the level of learning and training. Institutions of higher education are the chief agencies for fusion of progressive activities into an effective instrument of progress. Like progressive countries such as Pakistan though a developing country has tried to establish more and more institutions of higher education and universities to meet the challenges of the $21^{\text {st }}$ century.

Development is fundamentally a process of change that involves the whole society, its economics, sociocultural, political and physical structure as well as the value system and way of life of the people(Alexander, 1994). The goal of development is the improvement of human beings and the quality of their life. In International Encyclopedia of the Social Sciences volume no: 13 the term 'society' is defined as "A society is the group of human beings sharing a self sufficient system of action which is capable of existing longer than the life-span of an individual" (Sills, 1972). The term Society has been defined as "the social order or community life as a system within which the individual lives" (Philip, 1986). The society, as a well knit group of people, establishes a variety of institutions and agencies for meeting and augmenting its primary and secondary needs of the present as well as future (Shah, 1995). 
The founder of Pakistan, Mr. Muhammad Ali Jinnah's teachings was the guidelines for the entire nation in making the country a progressive and moderate welfare state (Shakaib, 2005). There is no doubt that Mr. Jinnah always envisioned Pakistan as a moderate, progressive Islamic country. Quaid-e-Azam said in his presidential address to the constituent Assembly on 11 August, 1947; "You are free to go to your temples. You are free to go to your Mosque or any other places or worship in the state of Pakistan. You may belong to a religion or cast or creed that has nothing to do with the business of state". It quite clearly indicates Quaid's vision of a moderate, tolerant Pakistan, Tolerance with in Muslims and tolerance outside Muslims with other religions (Govt. of Pakistan, 1947).

Pakistani culture is the unique pattern of belief, ideas and values highly influenced by religion. Ex. President of Pakistan, Pervez Musharraf envisioned envisaged the country's development not exclusively in the economic sense, but rather in a more holistic manner to include social, cultural and political dimensions. He envisioned that Pakistan will grow in terms of national unity and social cohesion, democracy and political stability, social justice, quality of life, national morale and pride (Musharraf, 2004). In moderate society, old conservative's thoughts about political, economic, social and religious system will have to be changed according to new emerging situation and trends (Musharraf, 2006).

Moderation is the "golden mean" between the extremes in human behaviour and is strongly recommended by Islam. 'A Basic Dictionary of Islam' defines 'moderation' as, "to do one's best to follow Islamic principles and practices without intolerance or extremism." So the reshaping the society on modern ways according to moral and Islamic tenets is called moderation and enlightenment (Maqsood, 2001).

The future of a society greatly depends on what type of education is imparted to its children. So efforts should be done to refashion it to reflect our spiritual, moral, and cultural values. Education has become a powerful tool inextricably and inseparably connected with the economic growth and social change of the nation, particularly so in a society where majority are illiterates living under stresses and strains of poverty, diseases, unemployment, moral dwarfs and spiritual bankruptcy. It has to play an indispensable and instrumental role in expediting the tempo of social change and development in all areas of the society giving priority to backward areas and people. The rise of internationalization, globalization of economics, knowledge culture and the concept of life long learning provides distinctive position to higher education both in national and international contexts. Through contribution of life long learning, competitiveness and the pursuits of excellence, college education has to play a significant role in society.

The study is significant as the best asset and the greatest treasure of any nation are its educational institutions. The colleges are best source of education; college education duration is from class 13 to class 16 . Pakistan's education system has an important role in determining how successful we shall be in achieving the goal of a progressive, moderate and democratic Pakistan. A key requirement is that the students must learn to understand and value this goal and cherish the values of truthfulness, honesty, responsibility, equality, justice, and peace that go with it.

\section{OBJECTIVES OF THE STUDY}

The objectives of this study were (a) to evaluate the role of tertiary education in preserving the moderate way of life in society as perceived by college teachers and students (b) to examine the gap between purely Islamic and purely secular education in the light of modern trends and essential requirements of Pakistani society as viewed by college teachers and students

\section{METHOD AND PROCEDURE}

Research is simply a systematic and refined technique of thinking, and employing special tools, instruments and procedures in order to obtain a more adequate solution of a problem. For this, survey was conducted to get the opinions of the respondents. Hence the nature of study was Descriptive/Survey type. 


\section{Population}

The population of the study comprised of: all the teachers working in public degree college and postgraduate colleges in Pakistan and all the students studying in these colleges. The study was further delimited to the degree and post graduate colleges of Pakistan in public sector.

\section{Sample}

The cluster sampling was used for selecting the study sample. The three teachers and nine students were randomly selected from each college. The three teachers and nine students were randomly selected from each college.

Table 1: Sample Colleges

\begin{tabular}{|c|c|c|c|}
\hline Territory & Male & Female & Total \\
\hline Punjab & 50 & 50 & 100 \\
\hline Sindh & 24 & 24 & 48 \\
\hline NWFP & 12 & 12 & 24 \\
\hline Baluchistan & 7 & 7 & 14 \\
\hline Federal & 7 & 7 & 14 \\
\hline Total & 100 & 100 & 200 \\
\hline
\end{tabular}

\section{Research Instrument}

The researcher prepared two questionnaires (one for teachers and second for students) using three-point rating scale after going through the related literature, consisting of books, journals, articles, reports and magazines with the help of honorable supervisor and members of supervisory committee. Their suggestions were incorporated in the questionnaires.

\section{Pilot Testing}

For the pilot testing, ten colleges were taken from district Rawalpindi and Lahore. It was further divided into five male and five female. The researcher personally visited and administered relevant questionnaires among, twenty teachers and one hundred students. They were requested to give their suggestions freely for the improvement of the questionnaire. They were also requested to amend the questions, if necessary in format and the language to make the questions simple and understandable. Accordingly, questionnaires were revised by incorporating their suggestions. Then the final version of questionnaires was developed.

\section{Data Collection}

The researcher visited most of the colleges of Punjab, NWFP and Federal Area personally and the remaining data were collected with the help of two research assistants and friends. Hundred percent data from sampled colleges were collected properly.

\section{Data Analysis}

Data collected through above-mentioned instruments were summarized in tables, question by question. In order to offer an overall picture on response to each question, the responses were coded:

$\begin{array}{lr}\text { Agree } & +1 \\ \text { Undecided } & 0 \\ \text { Disagree } & -1\end{array}$


The most suitable statistical tools like mean, standard deviation, standard error of mean, estimated population mean and Z-Value were applied for getting the results. The mean of the responses was shown. This offered a picture of the 'center of gravity' of the response patterns. Population range was determined and the lower limit of the range was used for interpretation purposes.

\section{RESULTS}

Table 2: Results Statistical Analysis

\begin{tabular}{|c|c|c|c|c|c|c|c|c|c|}
\hline & \multirow{2}{*}{ Selected Sample } & \multicolumn{7}{|c|}{ Reponses } & \multirow{2}{*}{ Z-Value } \\
\hline & & $\mathbf{N}$ & $\mathbf{A}$ & UN & DA & Mean & SD & $\mu$ & \\
\hline \multirow{2}{*}{$\begin{array}{l}\text { Educational system may } \\
\text { change individuals as desire }\end{array}$} & Teachers & 600 & 436 & 14 & 150 & 0.46 & 0.88 & .38 to .54 & \multirow[b]{2}{*}{2.25} \\
\hline & Students & 1800 & 1216 & 49 & 535 & 0.37 & 0.92 & .33 to .41 & \\
\hline \multirow{2}{*}{$\begin{array}{l}\text { College education gives the } \\
\text { sense of responsibility to } \\
\text { students. }\end{array}$} & Teachers & 600 & 402 & 33 & 165 & 0.39 & 0.88 & 31 to .47 & \multirow{2}{*}{3.75} \\
\hline & Students & 1800 & 1096 & 49 & 655 & 0.24 & 0.95 & .20 to .28 & \\
\hline \multirow{2}{*}{$\begin{array}{l}\text { College education improves } \\
\text { the women's status }\end{array}$} & Teachers & 600 & 420 & 27 & 153 & 0.42 & 0.94 & .34 to .50 & \multirow{2}{*}{3.80} \\
\hline & Students & 1800 & 1086 & 49 & 655 & 0.23 & 0.95 & .19 to .27 & \\
\hline \multirow{2}{*}{$\begin{array}{l}\text { College education removes } \\
\text { frustration }\end{array}$} & Teachers & 600 & 401 & 15 & 184 & .36 & .92 & .28 to .44 & \multirow{2}{*}{3.72} \\
\hline & Students & 1800 & 1057 & 48 & 695 & .20 & .97 & .16 to .24 & \\
\hline \multirow{2}{*}{$\begin{array}{l}\text { College education improves } \\
\text { confidence }\end{array}$} & Teachers & 600 & 492 & 05 & 103 & .64 & .76 & .58 to .70 & \multirow{2}{*}{4.00} \\
\hline & Students & 1800 & 1307 & 54 & 439 & .48 & .85 & .44 to .53 & \\
\hline \multirow{2}{*}{$\begin{array}{l}\text { It trains students to solve } \\
\text { various social problems. }\end{array}$} & Teachers & 600 & 260 & 25 & 315 & -0.09 & .98 & -.01 to. 17 & \multirow{2}{*}{0.75} \\
\hline & Students & 1800 & 804 & 69 & 927 & -0.06 & .97 & -.02 to. 10 & \\
\hline \multirow{2}{*}{$\begin{array}{l}\text { College education develops } \\
\text { generosity among students. }\end{array}$} & Teachers & 600 & 115 & 26 & 459 & -0.57 & .79 & -.51 to -.6 & \multirow{2}{*}{13.00} \\
\hline & Students & 1800 & 801 & 101 & 898 & -0.05 & .97 & -.01 to -.0 & \\
\hline \multirow{2}{*}{$\begin{array}{l}\text { It promotes protection of } \\
\text { minorities }\end{array}$} & Teachers & 600 & 429 & 10 & 161 & 0.44 & .89 & .38 to .50 & \multirow{2}{*}{3.75} \\
\hline & Students & 1800 & 1130 & 79 & 591 & 0.29 & .93 & .25 to .33 & \\
\hline \multirow{2}{*}{$\begin{array}{l}\text { College education awakens } \\
\text { love feelings for country }\end{array}$} & Teachers & 600 & 492 & 05 & 103 & 0.64 & .76 & .58 to .70 & \multirow{2}{*}{8.00} \\
\hline & Students & 1800 & 1157 & 69 & 574 & 0.32 & .92 & .28 to .36 & \\
\hline \multirow{2}{*}{$\begin{array}{l}\text { College education } \\
\text { generates employment } \\
\text { opportunities }\end{array}$} & Teachers & 600 & 531 & 04 & 65 & 0.78 & .62 & .72 to .84 & \multirow{2}{*}{14.3} \\
\hline & Students & 1800 & 1214 & 04 & 582 & 0.35 & .93 & .31 to .39 & \\
\hline \multirow{2}{*}{$\begin{array}{l}\text { College education creates } \\
\text { discipline among students. }\end{array}$} & Teachers & 600 & 197 & 12 & 391 & -0.32 & .93 & -.24 to -.4 & \multirow{2}{*}{4.75} \\
\hline & Students & 1800 & 763 & 39 & 998 & -0.13 & .98 & -.09 to -.1 & \\
\hline \multirow{2}{*}{$\begin{array}{l}\text { College education helps } \\
\text { society in eliminating } \\
\text { selfishness }\end{array}$} & Teachers & 600 & 156 & 52 & 392 & -0.39 & .87 & -.31 to -.4 & \multirow{2}{*}{4.75} \\
\hline & Students & 1800 & 692 & 64 & 1044 & -0.20 & .96 & -.16 to -.2 & \\
\hline \multirow{2}{*}{$\begin{array}{l}\text { Our education system is } \\
\text { strengthening the sense of } \\
\text { dignity in students. }\end{array}$} & Teachers & 600 & 141 & 19 & 440 & -0.49 & .84 & -.41 to -.5 & \\
\hline & Students & 1800 & 981 & 101 & 718 & 0.15 & .96 & .11 to .19 & 16.00 \\
\hline College education develops & Teachers & 600 & 87 & 12 & 501 & -0.69 & .71 & -.65 to -.7 & 255 \\
\hline acc & Students & 1800 & 1160 & 79 & 561 & 0.33 & .91 & .29 to .38 & 25.5 \\
\hline College curriculum is based & Teachers & 600 & 151 & 46 & 403 & -0.42 & .86 & -.36 to -.4 & 575 \\
\hline & Students & 1800 & 678 & 59 & 1063 & 0.21 & .96 & .17 to .25 & 0.15 \\
\hline
\end{tabular}




\section{Results Interpretation}

Table 2 indicates that the $\mu$ values for all Population range were determined and the lower limit of the range was used for interpretation purposes while $\mathbf{Z}$-Value shows that mean differences between teachers and students respondents of research items which the critical value at 0.05 levels.

In detail the researcher discuss as the above table 2 which shows that the research item educational system may change individuals as desire, mean rating score of sample students on the above statement was 0.37 , while rating score of sample teachers on the above statement was 0.46 , when generalized to the population, the mean rating score of students ranged from 0.33 to 0.41 and that of teachers from 0.38 to 0.54 . The teachers had moderately positive opinion, while students had slightly positive opinion about the statement. Their views significantly differed from each other, teachers' view being more favorable toward the statement. In the same way the item college education gives the sense of responsibility to students. Both the students and teachers had slightly positive opinion about the statement. However, their views significantly differed from each other, student's view being more favorable toward the statement. Likewise the item college education improves the women's status.

The teachers had moderately positive opinion, while students had slightly positive opinion about the statement. Their views significantly differed from each other, teachers' view being more favorable toward the statement. The research item college education removes frustration also indicates that both the students and teachers had slightly positive opinion about the statement. However, their views significantly differed from each other, student's view being more favorable toward the statement. In above table the research item college education improves confidence represents that both the students and teachers had moderately positive opinion about the statement. However, their views significantly differed from each other, teacher's view being more favorable toward the statement.

According to Shakaib (2005) college plays an effective role in developing personality and confidence to the youth. The same manner the item promotes protection of minorities indicates that the teachers had moderately positive opinion, while students had slightly positive opinion about the statement. Their views significantly differed from each other, teachers' view being more favorable toward the statement. The research item college education awakens love feelings for country though teachers had moderately positive opinion and students had slightly positive opinion about the statement. Their views significantly differed from each other, teacher's views being more favorable toward the statement. Similar the college education develops accountability in students towards Allah indicates that the teachers had moderately negative opinion, while students had slightly positive opinion about the statement. Their views significantly differed from each other, student's view being more favorable toward the statement. Moreover the nature and scope of college curriculum is based on Islamic ideology represents that the mean rating score of sample students on the above statement was 0.21 , while rating score of sample teachers on the above statement was -0.42 , when generalized to the population, the mean rating score of students ranged from 0.17 to 0.25 and that of teachers from -0.36 to -0.48 . The teachers had moderately negative opinion, while students had slightly positive opinion about the statement. Their views significantly differed from each other, student's view being more favorable toward the statement.

\section{DISCUSSION}

Education is considered as the most powerful instrument of social change. It is through education that society can bring changes and modernize itself. Tertiary education has a vital role to play because the susceptibility to change and capability for development among people can commensurate with level of learning and training. The study revealed that college education preserved the moderate way of life. According to the results it removed frustration and improved women status. Govt. of Pakistan also supported this observation. Significant and unprecedented program has been launched through the Ministry of women on national level for the implementation millennium landmark gender agenda, spread into three 5-year Plan, (1998-2013).

It was also revealed by the study that college education improved confidence, awoke sense of responsibility and helped to generate better employment opportunities. Isani and Virk (2004) in support of these ideas elaborated that institutions of higher education have main responsibility for equipping individuals with advanced knowledge and skills required for positions of responsibility in government, business and private enterprises. 
Majority of the students and teachers opined that college education did not train students to solve various social problems. Some traits like piety, generosity, tolerance etc would not be developed among the students in proper manner. Ihsan (1992) stated that the Islamic concept of social change is pragmatic and positive. The Islamic society is a model society that gives rise to democratic norms, values and life style. Some Muslim societies are under pressure of orthodox and conservative minded scholars, who create problems in establishing a moderate Islamic society. According to the study results, our education system strengthens the sense of honor and dignity, whereas, Channa (2004) also supported this idea. He stated that for the creating sense of dignity of labor, the college curriculum be revised. Both teachers and students expressed that college education has eliminated superstitious thoughts and helped to adopt the changes in the issues other than fundamental in Islam. Science cannot flourish in an atmosphere vitiated by obscurantism, dogmatism, fanaticism, intolerance and irrationalism. Science needs an intellectual and liberal environment which can only be created through enlightenment pragmatic approach and humanism (Masood, 2007). Respondents expressed that tertiary education developed the sense of accountability among students towards God (Allah). Both teachers and students held that education did not improve qualities like discipline, truthfulness, selflessness, morality and some other qualities.

Majority of the respondents viewed that due to the introduction of modernized curricula based on scientific and enlightened philosophy contributed in social mobility, cultural advancement, urbanization, management of public affairs, interpretation of scientific aspects of life and promotion of human rights. The respondents showed their dissatisfaction that tertiary education did not play its proper role for development of moderate society in Pakistan. Isani and Virk (2004) proposed that our higher education institutions must be helpful to meet the challenges of new emerging world and also meet expectations and growing demands of the student community as well as the moderate society. Both teachers and students expressed that college education helped to change the desirable behavior pertaining to moral empowerment of students, to gain knowledge to create sense of respect for law, to understand constitutional responsibilities and to promote love for country. College education has enabled women to work. A spirit of accommodation and tolerance could be promoted in the society with the help of good college education.

Both teachers and students revealed that the tertiary education did not promote Islamic direction of social change as moderate and balance change. Actually all these changes were unable to achieve because the population and sample under study covers only $3 \%$ of the students that entered in college/university education (Govt. of Pakistan, 2006). Society as a whole covers all types of people either literate or illiterate. The viewpoint of teachers is more positive about moderation of society in Pakistan, because the teachers' views and experience about practical life is comparatively stronger than the students.

\section{AUTHOR INFORMATION}

Samrana Atika is presently Ph.D. scholar in the University Institute of Education and Research, Pir Mehr Ali Shah Arid Agriculture University, Rawalpindi, Pakistan. drsamrana@gmail.com

\section{REFERENCES}

1. $\quad$ Alexander, K. 1994. The Process of development. Sega Publication, New Delhi, India. P.8.

2. Chandra, K.S. 1997. Education and Development. Discovery Publishing House, New Delhi, India. P.110.

3. Channa, D.M. 2004. Pakistan Journal of Education. A.I.O.U, Islamabad, Pakistan.

4. Govt. of Pakistan. 1947. Proceedings of All Educational Conference. Islamabad, Pakistan.

5. Ihsan, S. 1992. Systemic Social Change and Pakistan. Progressive Publishers, Lahore, Pakistan. P.96.

6. $\quad$ Iqbal, M. 1986. Pakistani Society. Aziz Publishers, Lahore, Pakistan. PP.440-441.

7. Isani and Virk, L. 2004. Higher Education in Pakistan, National Book Foundation, Islamabad, Pakistan. P.4

8. $\quad$ Maqsood, R.W. 2001. A Basic Dictionary of Islam. Talha Publications, Lahore, Pakistan. P. 142.

9. Masood, R. 2007. Social Change. Study Guide Unit No. 10, Allama Iqbal Open University, Islamabad, Pakistan. P. 6.

10. Musharraf, P. 2004. Time for Enlightened Moderation. June, 02. www.presidentofpakistan.gov.pk/enlightenedmoderation.asps. Searched on 26.11.2006. 
11. Musharraf, P. 2006. www.presidentofpakistan.gov.pk/enlightenedmoderation.asps Searched on 26.11.2006.

12. Philip, B.G. 1986. Webster Third New International Dictionary. Merriam Webster Inc. Publishers, Springfield, Massachusetts, USA. P.2162.

13. Shah, S.G.A. 1995. The College/University Teacher's Role in the Present Day Society. Sindh University Journal of Education, Vol. XXVIII. Hyderabad, Pakistan. PP. 73-78.

14. Shakaib, S. 2005. Moderate Reforms in Education. The Daily Frontier Post, $9^{\text {th }}$ August, Pakistan.

15. Sharif, M.Y. 1990. Proper Way Guide for Human Beings. Publisher M. Omer Haji Ghani, Karachi, Pakistan. PP. 482-484.

16. Sills, D.L. 1972. International Encyclopedia of the Social Science. Vol. 13. The Macmillan Company and the Free Press, New York, USA. P. 191. 
NOTES 